\title{
In-Vitro Antifungal Activity of Citrullus Colocynthis Schard Against Aflatoxigenic Aspergillus Flavus and Ochratoxigenic Aspergillus Ochraceus
}

\author{
Nora Nahal Bouderba ${ }^{1}$, Khalid Mohamed Khalid Elhussain ${ }^{2,3,4 *}$ and Hamid Kadi ${ }^{1}$ \\ ${ }^{1}$ Department of Biology, Faculty of Science of Nature and Life, Algeria \\ ${ }^{2}$ Department of Hematology, Faculty of Medical Laboratory Sciences, Omdurman Islamic university, Sudan \\ ${ }^{3}$ Faculty of Medicine, Omdurman Ahlia University, Sudan \\ ${ }^{4}$ International University of Africa, Faculty of Medical laboratory sciences, Sudan \\ *Corresponding author: Khalid M Khalid Elhussain, Department of Hematology, Faculty of Medical Laboratory Sciences, \\ Omdurman Islamic University, Sudan
}

\section{ARTICLE INFO}

Received: 幽 February 21, 2020

Published: 慧 March 03, 2020

Citation: Nora N B, Khalid Mohamed K E, Hamid K. In-Vitro Antifungal Activity of Citrullus Colocynthis Schard Against Aflatoxigenic Aspergillus Flavus and Ochratoxigenic Aspergillus Ochraceus. Biomed J Sci \& Tech Res 26(2)-2020. BJSTR. MS.ID.004316.

\section{ABSTRACT}

Background: Resistance to current antibacterial and antifungal drugs are growing global concerns. Traditional medicine is a potential source of new antibacterial and antifungal.

Objective: Aim is to study the effects of aqueous and methanolic of fruits leaves and roots of Citrullus colocynths Schard on fungal strain. Two methods have been used with this extracts on 2 fungal strains producer of mycotoxins; determination of growth radial technique on solid medium and determination of biomass technique on liquid medium. Aqueous and methanolic extract of fruit, leaves and root of Citrullus colocynths Schard; these are examined for their antifungal potentiality against Aspergillus flavus and Aspergillus ochraceous.

Result: The maximum percentage growth inhibition 100\% obtained from the aqueous extract from fruits of Citrullus colocynths Shard against Aspergillus Ochraceous. These extracts can be included in the list of herbal medicines due to their high antimicrobial potential.

Keywords: Citrullus colocynths Schard; Aspergillus flavus; Aspergillus ochraceous; Inhibition; Antifungal

\section{Introduction}

Citrullus Colocynths Schard is a member of the gourd family cucurbitaceae, originally from tropical Asia and Africa, it is now widely distributed in SaharanArabian phytogeographic region in Africa and the Mediterranean region [1]. It is small scarped perennial creeping herb with prostate or climbing stem, bearing smooth spherical fruits which are mottled green when young and some white yellow when ripe [2]. In moderate doses a drastic hydragogue, cathartic and diuretic; in large doses emetic and gastro-intestinal irritant; in small dose it is expectorant and alterative. Physician use this drug extensively as a drastic purgative in ascites and jaundice in various uterine conditions, especially in amenorrhea. Colocynth in the form of the solid extract enters many of the purgative pills of modern pharmacy. It is use full in biliousness, fever, intestinal parasites, constipation, hepatic and abdominal, visceral and cerebral congestions, dropsy, etc. Juice of the fruit 
mixed with sugar is a house-hold remedy in dropsy [3]. Citrullus colocynths has very high medicinal value; the plant contains three antitumor ingredients: cucurbitacin B, Cucurbitacin E and the D-glucoside of Beta- sitosterol [4]. The purpose of the present study is to investigate the antifungal activity of fruit (Bark and pulp), roots and leaves extract of Citrullus colocynth is against fungal strains were isolated from grains of stored cereal for human consumption.

\section{Materials and Methods}

\section{Plant Material and Sample Collection}

The plant used for the present study was collected in September 2011, from Owed Béchar, Béchar is a city in west Sahara, Department, Algeria. The leaves and roots were dried for 20 days in the dark at ambient laboratory temperature $\left(20\right.$ to $\left.28^{\circ} \mathrm{C}\right)$; the fruits were dried for three months at the same conditions, the grains were be debarrassed debarred, the different part were milled to a fine powder in an electrical mill, and stored in the dark room temperature in closed containers until required.

\section{Qualitative Phytochemical Screening}

Each organ of plant (leaves, roots and fruits) was screened for the presence of key families of phytochemicals (Sakar and Tanker, 1991; Trease and Evan, 1984). using the following reagents and chemicals: alkaloids with Mayer's reagents, Flavonoids with metallic magnesium and hydrochloridric acid, Spinosad's for their ability to produce suds, steroids acetic anhydride and concentrated sulphuric acid, Tanin with ferric chloride.

\section{Extraction Protocol}

Aqueous Extract: $5 \mathrm{~g}$ of different organs powder of plant were added to $50 \mathrm{ml}$ of distilled water, the mixture was allowed to reflux for $30 \mathrm{~min}$. After cooling it was filtered and stored to $4^{\circ} \mathrm{C}$ prior to analysis [5,6].

Hydroethanolic Extract: $5 \mathrm{~g}$ of different organs powder of plant were added to $50 \mathrm{ml}$ of methanol: distilled water $(1 \mathrm{~V} / 2 \mathrm{~V})$, the mixture was allowed to reflux for $30 \mathrm{~min}$. After cooling it was filtered. The filtrate was passed in a rotary evaporator at $65^{\circ} \mathrm{C}$ to vapor the methanol; the crude extract was stored to $4^{\circ} \mathrm{C}$ prior to analysis.

\section{Fungal Strains}

The fungal strains, A. Flavus and A. ochraceous; were obtained from durum wheat, they are isolate purify and identify in biology laboratory at Bechara university. Confirmation of Aspergillus genera was realized by micro culture method described by $[7,8]$. Furthermore, identification of A. flavus and A. ochraceous species was carried out by single spore method using three cultures media:
Malt Extract Agar( M.E.A) at $25^{\circ}$ C; Glycerol Nitrate Agar (G25N) at $25^{\circ} \mathrm{C}$ and Czapek Yeast Agar( C.Y.A) at $5^{\circ} \mathrm{C}$ and $37^{\circ} \mathrm{C}$. Using the identification key of Pitt (1973). Observation has been made after the first and second week. The fungal strains were stored in tubes of PDA acidified at $4^{\circ} \mathrm{C}$.

\section{Mycotoxigenic Test}

A. flavus and A. ochraceous were sowed on Y.E.S (Yeast Extract Sucrose) medium rich on B vitamin complex. After two weeks of incubation at $30 \pm 2^{\circ} \mathrm{C}$, the biomass was removed by filtration of Y.E.S medium. The filtrate was added then to $180 \mathrm{ml}$ of chloroform and stirred for $30 \mathrm{~min}$. After decantation, the organic layers were concentrated to $2 \mathrm{ml}$. Aflatoxin and ochratoxin were determined in each extract by spotting samples onto thin layer chromatography plate. Plate was developed with a toluene/Ethyl acetate/ Formic acid (50:40:10, v/v/v) solvent system. Aflatoxin and ochratoxin standard were spotted on the same plate as reference, aflatoxin and ochratoxins spots were identified using $365 \mathrm{~nm}$ UV [9]. The presence of Aflatoxins was provided by appearance of blue fluorescence for AFB and green fluorescence for OTA which have the same Rf as control.

\section{Antifungal Activity}

Evaluation of biomass or radial grow thing was achieved by counting of spores' number using Malassezia Hemet meter in order to obtain the concentration of 105 spores / $\mathrm{ml}$ [10].

Growth Radial Technique on Solid Medium: 1,2,3,4 and $5 \mathrm{ml}$ of fruit, root and leaves extract of Citrullus colocynthis were added to $20 \mathrm{ml}$ of PDA a (Potatoes Dextrose Agar acidified) solid medium; after agitation the select solution were transferred into a Petri plats which were incubated for 7 days at $25 \pm 2^{\circ} \mathrm{C}$ after ensemencing the fungal strain in the center. Mycelial radial growth was measured from the third day of incubation [11]. The inhibition percentage of mycelial growth of each extracts was calculated using the following formula:

$$
\mathrm{PI}=[(\mathrm{Dt}-\mathrm{D}) / \mathrm{Dt}] \times 100[11]
$$

Where Dt is mean diameter of mycelial growth in control and D is mean diameter of mycelial growth in treatment.

Biomass Technique on Liquid Medium: This technique consists to put different volumes of extract in flasks and completed them with 50ml of PDB a (Potatoes Dextrose Broth Acidified) in order to obtain different concentrations. These liquid cultures were sowed with $30 \mu \mathrm{l}$ of sporal suspension. The flasks were incubated for 14 days at $25 \pm 2^{\circ} \mathrm{C}$ [12] filtration, the filter paper was dried at $60^{\circ} \mathrm{C}$ during 24 hours [13]. Biomass weight formed P was determined using the following formula of Imtiaj and Lee [14].

$$
\text { [P=P1-P0] }
$$

Where P0 is the filter paper weight and P1 is the filter paper and fungal biomass weight after dryness. 


\section{Results}

\section{Qualitative Phytochemical Screening}

Phytochemical screening is usually carried out to screen for and to characterize the constituents available in a given plant sample. All phytochemical constituents tested were identified in Citrullus colocynthis fruits, leaves and roots as shown in Table 1.

Mycotoxigenic Test: The mycotoxin separation elaborated by the fungal strains was made on a CCM plate, the spots were revealed under the UV lamp at the wavelength $365 \mathrm{~nm}$, the elaboration of Aflatoxin B1 by A. flavus and ochratoxin A by A. ochraceous in the test are confirmed with CCM plate illustrate in Figures 1 \& 2 .

\section{Antifungal Activity}

Growth radial technique on solid medium: Different fractions of Citrullus colocynthis roots leaves and fruits were found to inhibit the growth of Aspergillus flavus and Aspergillus ochraceous. Different concentrations of aqueous and hydroethanolic extract for the three part of Citrullus colocynthis were tested for their efficacy against fungi of food stored with growth radial technique on solid medium; the result are presented in Figure 3. According to the results obtained it was found that A. flavus was $100 \%$ inhibited by the methanolic fruit extract and the aqueous root extract, while A. ochraceous was $100 \%$ inhibited by aqueous extract of fruits and methanolic extracts of leaves and roots. These results are shown on the Table 2.

Table 1: Phytochemical Screening of Citrullus colocynths fruits; leaves and roots.

\begin{tabular}{|c|c|c|c|}
\hline Phytochemical constituents & Fruits & Leaves & Roots \\
\hline _Alkaloid & + & $+/-$ & $+/-$ \\
\hline _ Tannins & + & $+/-$ & + \\
\hline _Saponins & + & $+/-$ & + \\
\hline _ Flavonoids & + & $+/-$ & + \\
\hline _ Unsaturated sterols and terpens & + & + & + \\
\hline _ Sterol and steroid & + & + & + \\
\hline
\end{tabular}

Key: +: present; -: Absent; +/-: low presence

Table 2: the inhibition percent of fungal strains tested with different concentrations of Citrullus colocynths extracts.

\begin{tabular}{|c|c|c|c|}
\hline \multirow{2}{*}{ Fruits } & Aqueous/ methanolic & A. Flavus ip (\%) & A. Ochraceus ip (\%) \\
\hline \multirow{2}{*}{ Leaves } & Aqueous & $88.46(21 \mathrm{mg} / \mathrm{ml})$ & $100(3.3 \mathrm{mg} / \mathrm{ml})$ \\
\cline { 2 - 4 } & Methanolic & $100(25.25 \mathrm{mg} / \mathrm{ml})$ & $100(33.66 \mathrm{mg} / \mathrm{ml})$ \\
\hline \multirow{2}{*}{ Roots } & Aqueous & $/$ & $77.77(18 \mathrm{mg} / \mathrm{ml})$ \\
\cline { 2 - 4 } & Methanolic & $100(10.8 \mathrm{mg} / \mathrm{ml})$ & $100(21.6 \mathrm{mg} / \mathrm{ml})$ \\
\cline { 2 - 4 } & Aqueous & $100(10.8 \mathrm{mg} / \mathrm{ml})$ & $75.55(13.5 \mathrm{mg} / \mathrm{ml})$ \\
\cline { 2 - 4 } & Methanolic & $44.23(8 \mathrm{mg} / \mathrm{ml})$ & $100(6.4 \mathrm{mg} / \mathrm{ml})$ \\
\hline
\end{tabular}

IP: Inhibition percent

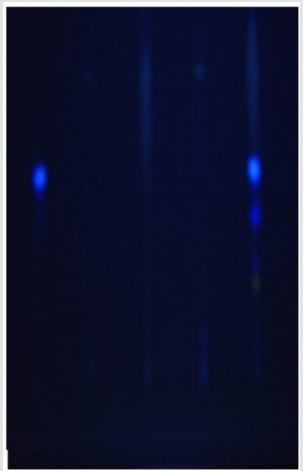

Figure 1: CCM plate of Aspergillus flavus strain.

Biomass Technique on Liquid Medium: In fact, the different results collected and recorded in Table 3 show a decrease in fungal biomasses proportional to the concentration of the extracts added to the medium with the exception of A. flavus with the aqueous extract of the leaves which gave an opposite effect. 
Table 3: Fungal biomasses according to the different concentrations of Citrullus colocynths extracts.

\begin{tabular}{|c|c|c|c|c|c|c|}
\hline \multicolumn{4}{|c|}{ Aqueous Extract } & \multicolumn{3}{|c|}{ Methanolic Extract } \\
\hline & $\begin{array}{l}\text { Concentrations } \\
(\mathrm{mg} / \mathrm{ml})\end{array}$ & A flavus (mg) & A ochraceus (mg) & $\begin{array}{l}\text { Concentrations } \\
(\mathrm{mg} / \mathrm{ml})\end{array}$ & A flavus (mg) & A ochraceus (mg) \\
\hline \multirow{6}{*}{ Fruits } & 0 & $250 \pm 08$ & $243 \pm 11$ & 0 & $250 \pm 08$ & $243 \pm 11$ \\
\hline & 2.7 & $191 \pm 05$ & $27 \pm 07$ & 5.31 & $195 \pm 23$ & $103 \pm 14$ \\
\hline & 5.5 & $127 \pm 10$ & $22 \pm 06$ & 11.2 & $137 \pm 11$ & $88 \pm 12$ \\
\hline & 8.1 & $100 \pm 09$ & $21 \pm 13$ & 17.8 & $96 \pm 05$ & $54 \pm 8$ \\
\hline & 10.8 & $96 \pm 11$ & $07 \pm 11$ & 25.25 & $89 \pm 08$ & $26 \pm 11$ \\
\hline & 13.5 & $78 \pm 15$ & $01 \pm 01$ & 33.66 & $61 \pm 14$ & $08 \pm 14$ \\
\hline \multirow{6}{*}{ Leaves } & 0 & $250 \pm 08$ & $243 \pm 11$ & 0 & $250 \pm 08$ & $243 \pm 11$ \\
\hline & 3.6 & $100 \pm 11$ & $120 \pm 04$ & 5.62 & $89 \pm 03$ & $142 \pm 16$ \\
\hline & 7.2 & $151 \pm 06$ & $113 \pm 09$ & 12.54 & $78 \pm 07$ & $137 \pm 15$ \\
\hline & 10.8 & $204 \pm 03$ & $78 \pm 10$ & 19.77 & $70 \pm 05$ & $130 \pm 07$ \\
\hline & 14.4 & $253 \pm 08$ & $65 \pm 10$ & 28.16 & $58 \pm 16$ & $69 \pm 08$ \\
\hline & 18 & $283 \pm 11$ & $65 \pm 15$ & 35.66 & $49 \pm 12$ & $63 \pm 11$ \\
\hline \multirow{6}{*}{ Roots } & 0 & $250 \pm 08$ & $243 \pm 11$ & 0 & $250 \pm 08$ & $243 \pm 11$ \\
\hline & 2.47 & $83 \pm 09$ & $137 \pm 05$ & 2.7 & $98 \pm 02$ & $86 \pm 03$ \\
\hline & 5.33 & $72 \pm 16$ & $130 \pm 08$ & 6.12 & $82 \pm 05$ & $77 \pm 08$ \\
\hline & 8.05 & $64 \pm 12$ & $125 \pm 12$ & 10.47 & $74 \pm 13$ & $59 \pm 07$ \\
\hline & 10.24 & $59 \pm 00$ & $67 \pm 06$ & 15.03 & $56 \pm 08$ & $38 \pm 05$ \\
\hline & 12.62 & $42 \pm 09$ & $58 \pm 05$ & 18.98 & $41 \pm 07$ & $22 \pm 03$ \\
\hline
\end{tabular}

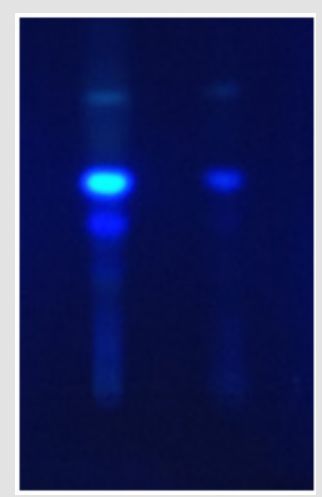

Figure 2: CCM plate of Aspergillus ochraceus strain.

\section{Discussion}

The traditional use of plants as medicines provide the basis for indicating which essential oils and plant extract may be useful for specific medical conditions $[15,16]$. The present investigation has explored the use of one such plant; Citrullus colocynthis Schard endemic in the south west of Algeria, for testing phytochemical compound and the antifungal activity of this endemic plant. Generally, in the phytochemical screening of any plant one normally identifies secondary metabolites that have accumulated to some extent at specific organ of the plant. These metabolites that are mainly used by the plant for protection against herbivores may have pharmacological activity when tested on animals [17]. Result of phytochemical screening of Citrullus colocynthis Schard fruits leaves and roots of showed the presence of saponins, sterols, steroid, terpene, flavonoids, tannin and alkaloids in different proportion in the tree part of plant. This result is in agreement with finding of [18]. which proved that alkaloids were found in all extracts except the roots, flavonoids were present only in seeds; gallic tannin and coumarins only in leaves, and all of them contained steroids. Ambit, et al. [2] confirmed that three phytochemical constituents were identified in Citrullus colocynthis Schard seeds extracts as alkaloid, steroid, glycosides and flavonoids. Extraction of secondary metabolites highly depends on using extractor techniques that depend on the chemical properties of these compounds. Water soluble compounds and proteins can be extracted in water or polar solvents whereas water insoluble compounds can be extracted with organic solvents [19]. Several authors Greyer and Harborne [20]; Yin and Cheng [21] have reported the fact that the extract of 
certain spices and herbs of medicinal importance exhibit antifungal property. These natural antifungal agents could be exploited in controlling the growth of fungi consequently inhibiting aflatoxin formation. All fungal strains have inhibited by the extracts tested at different concentration $3,3 \mathrm{mg} / \mathrm{ml}$ for A. ochraceous with fruits aqueous extract and $10.8 \mathrm{mg} / \mathrm{ml}$ for A. flavus and P. expanse with leaves hydroethanolic extract. It's interesting to mention that the hydro methanolic extracts are the most effective antifungal than aqueous extract because methanol allowed to extract well the less polar compound such as terpene drives [22]. Only A. flavus who noted a diameter and greater biomass than the control with the leaves aqueous extract. These data may be due to inoculum quality added on culture medium or strain using aqueous extract as carbon source. For Citrullus colocynthis Schard fruits; Belsem et al., 2009 reported the antifungal activity.

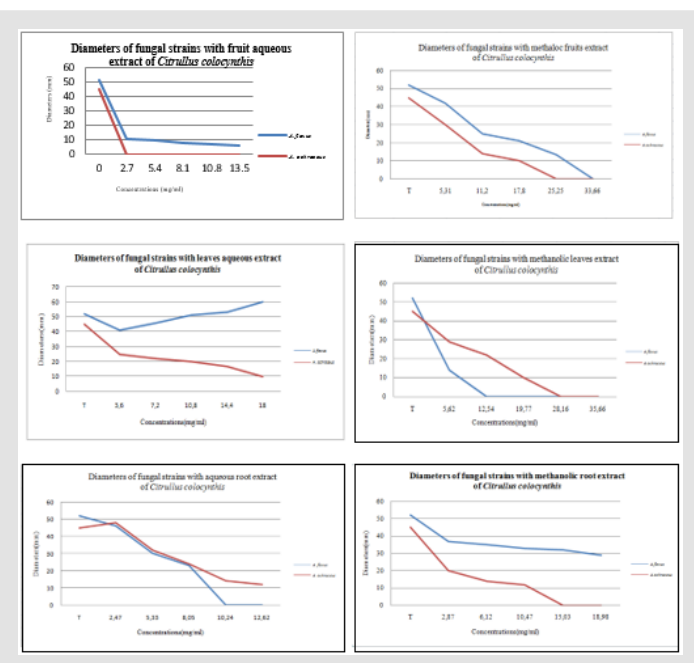

Figure 3: Antifungal activity of aqueous and methanolic extract of Citrullus colocynthis parts with Growth radial technique.

These results suggest that the inhibitory effect exhibited by the extract of Citrullus colocynthis Schard may be attributable to the secondary metabolites like phenolic compounds and saponins. Activity cannot be imputed to one family of phytochemical only; Alkaloids are commonly found to have antimicrobial properties [23]. Furthermore, tannins have been found in vitro to have various pharmacological properties such as antioxidant, antimicrobial and anti-inflammatory [24] Flavonoids are known to be synthesized by plants in response to microbial infection [25]. Antimicrobial and anticandidal activity may be attributed possibly in combination to various phytochemicals detected during. The extract chemical screening and which are known to cause damage to cell membrane, causing leakage of cellular materials and ultimately the microorganism's death [26-32].

\section{Conclusion}

The obtained results might be considered sufficient to prove that Citrullus colocynth this Schard extract can be considered a good antimicrobial agent; it can be used to con an antifungal overcoat against the strain that a major problem of producing mycotoxin, especially in stored foods. The results are only the first step of antimicrobial activity; further studies for the isolation and identification of the active principal and to the evaluation of possible synergism among extract component for their antimicrobial activity. Investigations are in progress to determine the degree of toxicity of these extract.

\section{References}

1. Feinbrun, Dothan N (1978) Flora Palaestina- Part III Jerusalem: The Israeli Academy of Sciences and Humanities pp. 380.

2. Shah CS, Qadry JS (1985) A Textbook of pharmacognosy ( $5^{\text {th }}$ Edn.). BS Shah, Prakashan, Pankore Naka, Ahmed abed, India, pp. 284.

3. Usman M, Abdulhakeem B, Syed Waseemuddin A, Iquba A, Husam B (2003) Antibacterial screening of Citrulluscolocynthis. Journal of pharmaceutical science 16(1): 1-6.

4. Rajkiran Chauhan, Urvija Garg, Tak RK (2011) Corrosion inhibition of aluminium in acid media by Citrulluscolocynthis extract. Journal of chemistry 8(1): 85-90.

5. Kadi H, Moussaoui A, Benmahdi H, Lazouni HA, Benyahia A, et al. (2011) Antibacterial activity of ethanolicndaqeous extract of PunicagranatumL bark. Journal of applied pharmaceutical science 1(10): 180-182.

6. Haris C (1989) Introduction to modern microbiology black wall scientific publication pp. 179.

7. Barnett HL (1972) Illustred general of imperfection fungi. Burgess publishing company, ( $3^{\text {rd }}$ Edn.). Minnesota, USA.

8. (1975) Association of Official Analytic Chemists, Natural poison 26, offitial methods of analysis. Association of Official Analytic Chemists Washington, DC, USA, p. 24.

9. Serghat SA, Mouria A, Ouazzanitouhami A, Badoc A, Douira A (2004) Effet de quelques fongicides sur le développement in vitro de pyriculariagrisea et helminthosporium oryzae. Bull Soc Pharm 143: 7-18.

10. Singh P, Kumar A, Dubey NK, Gupta R (2009) Essential Oil of Aeglemarmelos as a Safe Plant-Based Antimicrobial Against Postharvest Microbial Infestations and Aflatoxin Contamination of Food Commodities. Journal of food science 74 (6): 302-307.

11. Tubajika KM (2006) Efficacy of alkyl dimethyl benzyl ammonium chlorid on supression of physalospora vaccinii in laboratory assays. Journal of food protection 69(10): 2460-2464.

12. Dhandhukia PC, Thakkar VR (2007) Standardization of growth and fermentation criteria of Lasiodiplodiatheobromae for production of jasmonic Acid. African journal of Biotechnology 6(6): 707-712.

13. Ambi A, Abdurrahman EM, Sule MI, Pateh UU, Abdurrahman YR, et al. (2007) Phytochemical screening and histopathological studies on the seeds of colocynthis Cirullus inalbinos rats. Nigerian journal of pharmaceutical sciences 6(2): 7-12.

14. Hoffman DL (1987) The herb user's guide. Thorsons publishing group. Welling borough, UK.

15. Lawless J (1995) The illustrated encyclopedia of essential oils. Element books Ltd, Shaftesbury, UK.

16. Nahal-Bouderba N, Kadi H, Moghtet S, Meddah B, Moussaoui A (2012) Antibacterial activity and phytochemical screening of Oleaeuropaea leaves from Algeria. The open conference proceding journal 3: 66-69.

17. Kran KD, Diallo HA, Kouadio YJ (2009) Activités antifongiques de l'extrait de Chromolaenaodorata (L) King \& Robins sur deux isolats de Fusarium oxysporum (EFSm) responsables du jaunissement mortel des feuilles des bananiers. Journal of Applied Biosciences 24: 1488-1496. 
18. Cseke, Setzer W, Vogler B, Kirakosyan A, Kaufman P (2006) Traditional, analytical and preparative separation of natural products. Natural products from plants, CRC press/Taylor and francis, Boca Raton, Fla, USA, pp. 263-318.

19. Grayer RJ, Harborne JB (1994) A Survey of antifungal compounds from higher plants. Phytochemistry 37: 19-42.

20. Yin MC, Cheng WS (1998) Inhibition of Aspergi llusnigerand Aspergillusflavusby some herbs and spices. Journal of food protection 61(1): 123-125.

21. Emmanuel MA, Moudachirou M, Akakpo AJ, Quetin Leclercq J (2002) Activités antibactériennes in vitro de Cassia alata, Lantana camaraet Mitracarpusscabersur Dermatophiluscongolensis isolé au Bénin. Faculté des Sciences de la santé,Université d'Abomey Calavi Cotonou, Bénin ,Revue Pathologie Infectieuse communication 55(3): 183-187.

22. Omulokoli E, Khan B, Chhabra S (2007) Antiplasmodial activity of four kenyan medicinal plants. Journal of Ethnopharmacology 56(2): 133-137.

23. Soro S, Ouattara D, Guédé NZ, Coffi K (2010) Effet Inhibiteur in Vitro et in Vivo de l'extrait de Poudre et de l'huile Essentielle de Xylopia Aethiopica (Dunal) A Rich (Annonaceae) sur Fusariumoxysporum fsp Radicis-lycopersici (Forl), Champignon Parasite des Cultures de Tomate. European Journal of Scientific Research 39(2): 279-288.

24. Fogliani B, Raharivelomanana P, Bianchini JP, Bouraima Madjébi $S$ Hnawia E (2005) Bioactive ellagitanins from Cunoniamacrophylla, an endemic Cumoni-aceae from newCaledonia-Phytochemistry 66: 241 247.

\section{ISSN: 2574-1241}

DOI: 10.26717/BJSTR.2020.26.004316

Khalid Mohamed Khalid Elhussain. Biomed J Sci \& Tech Res

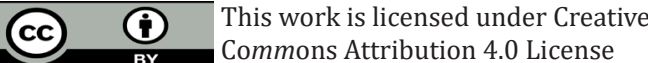

Submission Link: https://biomedres.us/submit-manuscript.php
25. Mshvildadze V, Favel A, Delmas F, Elias R, Faure R, et al. (2000) Antifungal and antiprotozoal activitys of saponins from Hedera colchica. Pharmazie 55(4): 325-326.

26. Abdel ghani SB, Weaver L, Zidan ZH, Hussein MA, Keevil CW, et al. (2008) Microware-assisted synthesis and antimicrobial activities of flavonoid derivative. Bioorganic and medical chemistry letters 18(2): 518-522.

27. Belsem M, Marzouk Z, Décor R, Edziri H (2009) Antibacterial and anticandidal screening of Tunisian Citrulluscolocythis Schrad From Medenine. Journal of Ethnopharmacology 125(2): 344-349.

28. Curtay, Jung (2010) Jus de grenade fermenté. ( $2^{\text {nd }}$ Edn.). Macro pitteur, Belgique p. 10-20.

29. Hibar K, Daami-Remadi M, Jabnoun-Khiareddine H, Znaidi I, Elmahjoub M (2006) Effet des extraits de compost sue la croissance mycélienne et l'agressivité du Fusariumoxysporumf. sradicislycopersici. Biotechnol Agron Environ 10(2): 101-108.

30. Imtiaj A, Lee TS (2007) Screening of antibacterial and antifungal activities from Korean wild mushrooms. World journal of agricultural sciences 3(3): 316-321.

31. Murray PR, Baron EJ, Pfaller MA, Tenover FC, Yolke RH (1999) Manual of clinical microbiology. ASM: Washington, USA, 6: 51-59.

32. Pitt JI (1973) An appraisal of identification methods for Penicillium species: Novel taxonomic criteria based on temperature and water relations. Mycology 65(5): 1135-1157.

33. Ramirez C (1982) Manual and Atlas of Penicillia. Elsevier biomedical press, New York, USA

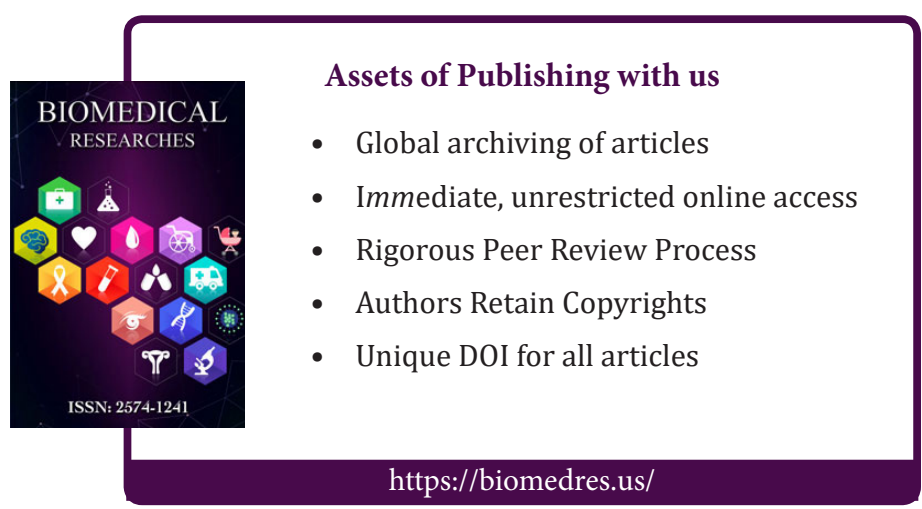

